Virginia Commonwealth University vCU Scholars Compass

2008

\title{
Impaired Clearance of Methotrexate in Organic Anion Transporter 3 (Slc22a8) Knockout Mice: A Gender Specific Impact of Reduced Folates
}

\author{
Adam L. VanWert \\ Medical University of South Carolina \\ Douglas H. Sweet \\ Virginia Commonwealth University, dsweet@vcu.edu
}

Follow this and additional works at: http://scholarscompass.vcu.edu/pceu_pubs

Part of the Pharmacy and Pharmaceutical Sciences Commons

Copyright (C) 2007, Springer Science+Business Media, LLC. This is the author's manuscript of a work that was accepted for publication in Pharm Res. 2008 Feb; 25(2):453-462. The final publication is available at Springer via http://dx.doi.org/10.1007/s11095-007-9407-0

\section{Downloaded from}

http://scholarscompass.vcu.edu/pceu_pubs/12

This Article is brought to you for free and open access by the Dept. of Pharmaceutics at VCU Scholars Compass. It has been accepted for inclusion in Pharmaceutics Publications by an authorized administrator of VCU Scholars Compass. For more information, please contact libcompass@vcu.edu. 


\title{
Impaired Clearance of Methotrexate in Organic Anion Transporter 3 (S/c22a8) Knockout Mice: A Gender Specific Impact of Reduced Folates
}

\author{
Adam L. VanWert ${ }^{1}$ and Douglas H. Sweet ${ }^{1,2}$ \\ ${ }^{1}$ Department of Pharmaceutical Sciences, Medical University of South Carolina, 280 Calhoun Street \\ (Rm. QE218)P.O. Box 250140 Charleston, South Carolina 29425, USA.
}

\begin{abstract}
Purpose-To elucidate the role of the renal basolateral transporter, Oat3, in the disposition of methotrexate.

Materials and Methods-Chinese hamster ovary cells expressing mouse Oat 3 were used to determine kinetics and specificity of inhibition of methotrexate transport. Methotrexate clearance was then examined in vivo in wildtype and Oat3 knockout mice.
\end{abstract}

Results-NSAIDs, ß-lactams, and uremic toxins inhibited mOat3-mediated methotrexate uptake by $70-100 \%$, while folate, leucovorin, and 5-methyltetrahydrofolate inhibited transport by $25-50 \%$. A $K_{\mathrm{m}}$ of $60.6 \pm 9.3 \mu \mathrm{M}$ for methotrexate transport was determined. Oat3 knockout mice exhibited reduced methotrexate-to-inulin clearance ratios versus wildtype. Male wildtype mice, but not knockouts or females, demonstrated significantly accelerated methotrexate clearance in response to reduced folates. Reduced folates also markedly inhibited hepatic methotrexate accumulation in males, but not females, and the response was independent of Oat 3 function.

Conclusions-Oat 3 contributes to methotrexate clearance, but represents only one component responsible for methotrexate's elimination. Therefore, in patients, dysfunctional hOAT3 polymorphisms or drug competition for hOAT3 transport may severely impact methotrexate elimination only when redundant means of methotrexate removal are also compromised. Furthermore, the present findings suggest that reduced-folate administration only influences methotrexate disposition in males, with the renal reduced-folate response influenced by OAT3 function.

\section{Keywords}

cancer; carrier; chemotherapy; polymorphisms; renal secretion

\section{INTRODUCTION}

Methotrexate (MTX) is a commonly employed chemotherapeutic agent prescribed for various cancers and rheumatic diseases (1). The therapeutic and detrimental cytotoxic effects of this folate antimetabolite are linked to its ability to potently compete with folic acid metabolism, resulting in impaired DNA synthesis and thus reduced cell proliferation (2). In order for MTX to act as a folate antimetabolite, it must first reach the intracellular dihydrofolate reductase

() 2007 Springer Science + Business Media, LLC

2To whom correspondence should be addressed. (sweetd@ musc.edu). 
enzyme $(3,4)$. Being an organic anion, cellular entry of MTX is dependent upon transport mechanisms in plasma membranes, which are pivotal for efficient entry of charged molecules into the cell $(2,5,6)$. Thus, interpatient variability in both toxic and therapeutic responses to MTX is potentially caused, in part, by interpatient variability in organic anion transport mechanisms (7). This variability may result from differences in transporter expression/function (e.g., polymorphisms) or transporter burden (i.e., MTX-substrate interactions).

Many different transporters have been shown to interact with MTX in vitro (Table I). Based on these in vitro findings, carriers that can transport MTX include organic anion transporters (OAT) 1 to 4 (5-13), multi drug resistance-associated proteins (MRP) 1 to 4 (8-11), the reduced folate carrier (RFC-1; 12,13), organic anion transporting polypeptide (OATP) 1A2 (14), and OAT-K1/K2 $(15,16)$. Since MTX's major route of elimination is renal, and it is substantially bound to plasma protein (1), renal secretion of MTX plays an important role in its elimination and nephrotoxicity. Pivotal to secretion is proximal tubular basolateral transport, a function that depends on an array of carrier proteins including the basolateral organic anion exchangers Oat1 and Oat3 $(17,18)$. Experiments using renal slices, a model system which tracks basolateral uptake across a native renal proximal tubule epithelium, indicate that the most likely contributors to renal basolateral MTX transport are Oat3 and RFC-1 (13). These transporters both have relatively strong affinities for MTX (Table I) and it has been suggested that they play equal roles in MTX uptake in rat kidney; together accounting for the majority of basolateral MTX uptake into proximal tubular cells (13).

Various drugs that interact with human OAT3 (hOAT3) in vitro, e.g., penicillins, probenecid, and nonsteroidal anti-inflammatory drugs (NSAIDs), have been shown to elevate the blood level of MTX in patients when administered concomitantly (1). The reduced folate, leucovorin (5-formyltetrahydrofolate), is administered after termination of MTX therapy to rescue patients from the cytotoxic effects of MTX and is a substrate for basolateral hRFC-1 (19). However, studies in rats indicate that instead of reducing MTX renal elimination through competition on rRFC-1, leucovorin stimulates MTX renal elimination, possibly by exchanging for MTX on an apical transporter(s; 20). Further studies are necessary to determine which transporters are responsible in vivo for drug interactions and interpatient variability in MTX elimination and toxicity.

As mentioned previously, hOAT3 interacts relatively strongly with MTX in vitro (Table I). Moreover, a number of human $O A T 3$ polymorphisms have been identified and shown to yield transport proteins of marked functional heterogeneity (21). With some mutants, substrate specificity is altered, and with others, transport is completely abolished (21). Taken together, this suggests hOAT3 substrate competition and/or polymorphisms as underlying causes of variability in MTX elimination and nephrotoxicity in vivo. Thus, in the present study, substrate competition on, and kinetics of MTX transport by, murine Oat 3 was determined in vitro. This information was then used to design in vivo experiments in wildtype and Oat 3 knockout mice to directly examine the role of Oat 3 in the elimination and distribution of MTX, as well as in MTX-reduced folate interactions.

\section{MATERIALS AND METHODS}

\section{Isolation of Stably Transfected Cell Lines}

The pBlue-scriptSK/Roct (mOat3) vector containing the full-length murine Oat3 (Roct) cDNA clone (GenBank Accession no. AF078869) was a generous gift from Dr. David R. Beier (22). The mOat3 plasmid was transformed into Escherichia coli, amplified, and purified according to standard laboratory protocols. All manipulations were done in accordance with the procedures outlined by the Medical University of South Carolina Institutional Biosafety 
Committee registration for infectious agents and recombinant DNA (IBC\#2123-9 and IBC\#2123-10, reapproved 02/01/2007).

CHO-FlpIn cells were purchased from Invitrogen (Carlsbad, CA) and maintained at $37^{\circ} \mathrm{C}$ with $5 \% \mathrm{CO}_{2}$ in Ham's F12 medium (Mediatech, Inc., Herndon, VA) containing 10\%

SerumSupreme (Cambrex, Walkersville, MD) and $100 \mu \mathrm{g} / \mathrm{ml}$ zeocin (Invitrogen). Isolation of the control "mock" transfected cell line stably transformed with the empty pcDNA5/FRT vector (CHO-FRT cells) has been described previously (23). The experimental line stably transformed with a pcDNA5/FRT-mOat3 vector, designated CHO-mOat 3 cells, was made for this study. Briefly, the pcDNA5/FRT-mOat3 vector was constructed by gel isolating the $\sim 2.0$ $\mathrm{kbp}$ full-length mOat3 Sal1-Not 1 fragment from the pBluescriptSK/mOat 3 vector and ligating it into Sal1-Not1 cut pcDNA5/FRT vector. For transfection, cells $\left(2 \times 10^{5}\right)$ were plated into individual wells of a six well culture plate and grown overnight. Cells were transfected with 1 $\mu \mathrm{g}$ pcDNA5/FRT-mOat3 DNA and $8 \mu \mathrm{g}$ pOG44 DNA overnight at $37^{\circ} \mathrm{C}$ using Transfectin Lipid Reagent ( $2 \mu \mathrm{l}$ Transfectin/ $\mu \mathrm{g}$ DNA; Bio-Rad, Hercules, CA). After $24 \mathrm{~h}$ the medium was replaced with fresh medium containing $500 \mu \mathrm{g} / \mathrm{ml}$ hygromycin B (Invitrogen). Cell clones were selected with $500 \mu \mathrm{g} / \mathrm{ml}$ hygromycin B for 4 weeks and maintained in $125 \mu \mathrm{g} / \mathrm{ml}$ hygromycin B after testing positive for organic anion transport activity.

\section{Cell Transport Assays}

Cells $\left(2 \times 10^{5}\right.$ per well) were seeded in 24 -well tissue culture plates and grown for 2 days ( $37^{\circ}$ $\mathrm{C}, 5 \% \mathrm{CO}_{2}$ ) in the absence of antibiotics. Before initiation of transport experiments, the culture medium was removed and the cells were equilibrated for 10 min with transport buffer (Hanks' balanced salt solution containing 10 mM HEPES, pH 7.4; Sigma-Aldrich, Saint Louis, MO). The equilibration medium was removed before a final application of $500 \mu \mathrm{l}$ of transport buffer containing $10-500 \mu \mathrm{M}\left[{ }^{3} \mathrm{H}\right] \mathrm{MTX}(0.5 \mu \mathrm{Ci} / \mathrm{ml})$ in the absence or presence of inhibitors $(1 \mathrm{mM})$ as indicated. After incubation at room temperature for the indicated times, the uptake solution was removed and the cells were rinsed rapidly three times with $1 \mathrm{ml}$ of ice-cold transport buffer. The cells were dissolved in $500 \mu \mathrm{l}$ of $1 \mathrm{M} \mathrm{NaOH}$ and neutralized with $50 \mu \mathrm{l}$ of $10 \mathrm{M} \mathrm{HCl}$. Aliquots were removed and analyzed for protein content using a BCA protein assay kit (Pierce, Rockford, IL) and by liquid scintillation counting. Uptake was calculated as picomoles of substrate per mg of protein. Transformations for kinetic calculations were performed using GraphPad Prism software, and the $K_{\mathrm{m}}$ was calculated from the x intercept of the LineweaverBurk plot. All experiments were repeated three times in triplicate to confirm results.

\section{Animals}

Wildtype and Oat3 knockout age-matched C57BL/6 mice (10-16 weeks old) were used in the present study. Mice were allowed food and water ad libitum and were housed in animal facilities maintained by the Medical University of South Carolina Division of Laboratory Animal Resources. The MUSC program for laboratory animal care has an assurance statement on file with the NIH Office for the Protection from Research Risks/Department of Health and Human Services and has maintained full accreditation with the Association for Assessment and Accreditation of Laboratory Animal Care since 1987. All animal procedures were approved by the MUSC Institutional Animal Care and Use Committee (AR\#2082, reapproved 9/1/2006).

\section{Plasma Elimination and Organ Distribution}

Wildtype and Oat3 knockout mice were administered $100 \mu \mathrm{Ci} / \mathrm{kg}\left[{ }^{3} \mathrm{H}\right] \mathrm{MTX}$ and $10 \mu \mathrm{Ci} / \mathrm{kg}$ $\left[{ }^{14} \mathrm{C}\right]$ inulin concomitantly by bolus tail vein injection with normal saline as vehicle (total injection volume was $5 \mu$ per gram of mouse weight). Unlabeled MTX with or without combined reduced folates (5-methyltetrahydrofolate with leucovorin at a tenfold molar excess over MTX) were included in the bolus injection in the indicated experiments to test the effect 
of MTX dose and reduced folates on elimination. The MTX dose in "clinical dose" experiments was $1.7 \mathrm{mg} / \mathrm{kg}$, yielding an initial plasma level of $\sim 20 \mu \mathrm{M}[10-1,000 \mu \mathrm{M}$ is commonly observed in humans (1)]. Serial blood samples $(\sim 35 \mathrm{ml})$ were obtained at 1, 5, 10, 15, 20, and $30 \mathrm{~min}$, and were centrifuged to obtain plasma. At $30 \mathrm{~min}$, the mice were sacrificed and organs were harvested, rinsed, blotted, weighed, and homogenized prior to scintillation spectroscopy. Samples were counted in a Packard Tri-Carb 2900 TR liquid scintillation counter with external quench correction and microcuries were converted to moles of substrate. For each experiment, an aliquot of the freshly prepared stock $\left[{ }^{3} \mathrm{H}\right] \mathrm{MTX} /\left[{ }^{14} \mathrm{C}\right]$ inulin injection solution was counted in order to determine the exact $\mu \mathrm{Ci} / \mu \mathrm{g}$ of MTX and inulin. This afforded accurate determinations of MTX and inulin plasma concentrations as well as the precise MTX and inulin doses to enter into the WinNonlin ${ }^{\circledR}$ program for pharmacokinetic calculations.

\section{Pharmacokinetic and Statistical Analyses}

Plasma clearance determinations were performed using WinNonlin ${ }^{\circledR}$ software (Pharsight Corporation, Mountain View, CA). Two-compartment IV-bolus modeling was used with micro constants (pharmacokinetic model \#7) and resulted in the lowest coefficients of variation for kinetic parameters as compared to other models. Statistical significance of elimination curves was determined using two-way ANOVA and posthoc analyses were not conducted. The student's $t$ test was used for all other comparisons. The $\alpha$ for significance is 0.05 .

\section{Materials}

Unlabeled MTX was acquired from MP Biomedicals (Solon, OH) and $\left[{ }^{3} \mathrm{H}\right] \mathrm{MTX}(12 \mathrm{Ci} / \mathrm{mmol})$ was acquired from Moravek Biochemicals (Brea, CA). $\left[{ }^{3} \mathrm{H}\right]$ Estrone-3-sulfate $(50 \mathrm{Ci} / \mathrm{mmol})$ and $\left[{ }^{14} \mathrm{C}\right]$ inulin $(0.0095 \mathrm{Ci} / \mathrm{mmol})$ were acquired from American Radiolabeled Chemicals (Saint Louis, MO). Folic acid, folinic acid (leucovorin), and 5-methyltetrahydrofolate (5$\mathrm{CH}_{3}$-THF) were acquired from Sigma-Aldrich (Saint Louis, MO). All other reagents were purchased from standard sources. Structures of all chemicals can be obtained from their suppliers' websites.

\section{RESULTS}

\section{mOat3-mediated Transport of MTX In Vitro}

mOat3-mediated uptake of estrone-3-sulfate in CHO-mOat3 cells was $\sim 22$ times greater than nonspecific uptake (Fig. 1). Accumulation of MTX was $\sim$ fourfold greater than control (Fig. 1). Uptake of both compounds was completely inhibited by $1 \mathrm{mM}$ probenecid. The background MTX signal in Chinese hamster ovary cells was low. The timecourse of MTX uptake into CHO-mOat 3 cells indicated that cellular accumulation was linear for the first 10 min (Fig. 2a). Therefore, kinetic measurements were determined using a 5 min uptake duration. Fig. $2 \mathrm{~b}$ demonstrates saturable uptake of MTX into CHO-mOat 3 cells and linear nonspecific accumulation in CHO-FRT cells. Fig. 2c illustrates the Lineweaver-Burk transformation for determining transport kinetic values. The calculated $K_{\mathrm{m}}$ from three experiments is $60.6 \pm 9.3$ $\mu \mathrm{M}$.

Various classes of organic anions markedly inhibited mOat3-mediated MTX uptake (Fig. 3), including NSAIDs (salicylate and indomethacin), uremic toxins (uric acid and indoxyl sulfate), neurotransmitter metabolites (dihydroxyphenylacetic acid and hydroxyindoleacetic acid), Blactam antibiotics (penicillin G), sulfated steroid hormone conjugates (estrone-3-sulfate), and prototypical organic anion transporter substrates/inhibitors ( $p$-aminohippurate, probenecid, and bromosulfophthalein). Folate and two reduced folates, leucovorin and 5methyltetrahydrofolate, exhibited differential potencies for inhibition of mOat3 (Fig. 3). Folate and 5-methyltetrahydrofolate each inhibited mOat3-mediated MTX transport by 50\%, whereas leucovorin demonstrated less than $30 \%$ inhibition, each at a concentration 100 times 
greater than that of MTX. The cation, tetraethylammonium, did not significantly inhibit MTX transport on mOat3 (Fig. 3).

\section{In Vivo Plasma Elimination of MTX in Wildtype and Oat3 Knockout Mice}

Male wildtype and Oat3 knockout mice exhibited similar plasma levels of MTX to each other at both tracer and "clinical" doses (Fig. 4a and b). When administered concomitantly with reduced folates, MTX plasma levels were significantly elevated in Oat3 knockout males as compared to wildtype (Fig. 4c). Inulin plasma levels were not significantly different between male wildtype and Oat3 knockout mice for all MTX treatments studied (Fig. 4d-f).

In contrast, female Oat3 knockout mice had significantly elevated plasma levels of MTX at the "clinical" dose compared to wildtype mice (Fig. 5a). When administered concomitantly with reduced folates, MTX plasma levels were similar between wildtype and Oat3 knockout females (Fig. 5b). Inulin plasma levels were not significantly different between female wildtype and Oat3 knockout mice for either of the treatment conditions studied (Fig. $5 \mathrm{c}$ and d).

In order to control for possible interanimal variation in hemodynamics and glomerular filtration, the MTX-to-inulin clearance ratio was calculated separately for each mouse (Fig. 6). Two different comparisons are presented (wildtype versus Oat3 knockout mice and male versus female mice) using the same data. For all conditions, MTX plasma clearance was greater than inulin plasma clearance (i.e., clearance ratio $>1.0$ ). The mean inulin plasma clearance value for all mice in this investigation was $13.57 \pm 0.64 \mathrm{ml} \mathrm{min}^{-1} \mathrm{~kg}^{-1}(n=30)$. Male Oat3 knockout mice exhibited a reduced clearance ratio with tracer, but not "clinical," MTX dose as compared to wildtype mice (Fig. 6a). In contrast, the clearance ratio was significantly reduced in female Oat3 knockout mice given "clinical" dose MTX (Fig. 6a). Concomitant reduced-folate administration increased the MTX-to-inulin clearance ratio in male wildtype mice, but not in female wildtype mice or Oat3 knockout mice of either gender (Fig. 6a). Female wildtype mice demonstrated a greater MTX-to-inulin clearance ratio than male wildtype mice, but no gender differences were observed for any other comparisons (Fig. 6b).

\section{In Vivo Distribution of MTX in Wildtype and Oat3 Knockout Mice}

MTX concentrated in the liver and kidneys of male and female mice of both genotypes $30 \mathrm{~min}$ after IV bolus administration (Fig. 7). However, testes, ovaries, skeletal muscle, and brain all exhibited tissue-to-plasma MTX ratios less than 1 (Fig. 7). In the presence of reduced folates, male Oat3 knockout mice demonstrated significantly reduced liver, testes, and brain tissue-toplasma MTX ratios compared to wildtype mice. In marked contrast to male knockout animals, female Oat3 knockout mice demonstrated significantly reduced liver, kidney, and brain tissueto-plasma MTX ratios only in the absence of reduced folates (Fig. 7). Female wildtype, but not Oat3 knockout, mice exhibited reduced tissue-to-plasma MTX ratios in the liver and kidneys in response to reduced-folate inhibition (Fig. 7).

Absolute renal and hepatic accumulation was also assessed in order to identify inherent organ differences in MTX accumulation under the different conditions (Fig. 8). Male wildtype mice exhibited a substantial reduction in renal MTX accumulation in response to reduced folates, while there was little to no response to reduced folates by male Oat 3 knockout and female mice of both genotypes (Fig. 8a). Male wildtype and Oat3 knockout mice exhibited markedly reduced liver accumulation of MTX in response to reduced folates (Fig. 8b). While significance was not achieved in male wildtype mice, when male wildtype and Oat3 knockout liver data are pooled together, the effect of reduced folates is more significant than in knockouts alone (from a $p$ value of $<0.05$ (KO) to a $p$ value of $<0.01$ (pooled)). In stark contrast to males, but similar to the renal response observed in females, hepatic accumulation in female mice was virtually unresponsive to reduced folates (Fig. 8b). For Oat3 knockout animals, plasma levels 
were similar within genders comparing the presence and absence of reduced folates (Figs. 4 and 5), indicating that differences in kidney and liver accumulation were not simply due to differences in blood levels, but inherent differences in the organs themselves.

\section{DISCUSSION}

MTX is a commonly used cancer chemotherapeutic and antirheumatic agent. It is effective in treating breast, lung, and bone cancer, as well as leukemia, and is considered the "gold" standard for treatment of rheumatoid arthritis (1). While this pharmacotherapeutic has benefited many patients, its cytotoxic effects are nonspecific and detrimental to healthy cells, as is the case with the majority of cancer chemotherapeutics. The disposition of MTX, and therefore its toxicity, is influenced by drug interactions reportedly involving transport proteins in barrier epithelia (1,7). The majority of MTX is eliminated renally in humans as the parent compound within $24 \mathrm{~h}$ after an IV dose (80-90\%), with substantial plasma protein binding placing a large burden on renal active secretory mechanisms (1). Alterations in renal proximal tubular secretion of MTX can therefore affect MTX systemic levels and nephrotoxicity.

An essential component of renal net secretion is baso-lateral uptake, a process that depends on transport proteins in the plasma membrane. MTX's interaction with two renal basolateral transporters, human OAT3 and RFC-1, is substantial in vitro (24-26), indicating that these exchangers may be important sources of variable MTX pharmacokinetics between patients and under different substrate burden scenarios (e.g., polypharmacy with interacting drugs). Of pivotal relevance to this is the recent discovery of human polymorphisms in an ethnically diverse population resulting in heterofunctional hOAT3 protein (21). Out of the ten distinct protein-altering variants identified, three resulted in complete loss of hOAT3 function, and others resulted in significantly reduced function, when assessed for estrone-3-sulfate and cimetidine transport (21). The observation that some OAT3 polymorphisms present in humans result in completely non-functional transporter protein highlights the importance of determining the consequences of OAT3 dysfunction in an intact organism.

Previous characterization of MTX transport in heterologous Oat 3 expression systems has been limited to the human and rat orthologs $(13,24,25)$. Therefore, prior to in vivo analyses, we sought to determine the specificity and kinetics of MTX transport on mOat3. It was observed that MTX interacts with mOat3 much like hOAT3, and all compounds tested that are known to inhibit hOAT3 also inhibited mOat3 (Fig. 3;27). The known OAT3/Oat3 inhibition profile suggests that the numerous MTX-drug interaction case reports in humans may be mediated, in part, by competition on hOAT3 (1). However, drug interactions with MTX involving transporters are also likely to occur on the apical aspect of renal proximal tubule cells, as well as hepatically, and in other barrier membranes (Table I). To this regard, it has been shown that NSAIDs interfere with MTX transport by the apically-targeted hMRP2 and hMRP4 (8), and MTX is transported by apical hOAT4 and rOAT-K1/K2 $(25,28)$.

Interestingly, in the current study, three known substrates of hRFC-1, folate, leucovorin, and 5-methyltetrahydrofolate, also inhibited mOat3, providing novel information regarding the specificities of these compounds for renal basolateral transporters. Folate and leucovorin have not previously been assessed for their ability to interact with Oat 3 orthologs, but 5methyltetrahydrofolate has been demonstrated to inhibit rOat3 (13). The interaction of folate, as well as the reduced folates, with mOat3, was weaker than most of the other anions tested. These findings suggest that, like their analog MTX, folate and the reduced folates may be substrates for OAT3 and RFC-1, both renal proximal tubular basolateral exchangers. Finally, MTX uptake in CHO-mOat3 cells was clearly saturable with an estimated $\mathrm{K}^{\mathrm{m}}$ of $60.6 \pm 9.3$ $\mu \mathrm{M}$ for mOat3 (Fig. $2 \mathrm{~b}$ and c), which is comparable to the reported $\mathrm{K}^{\mathrm{m}}$ for hOAT3 of $\sim 20 \mathrm{mM}$ $(24,25)$, indicating that mOat3 and hOAT3 have similar affinities for MTX (Table I). 
While MTX has been shown to interact with a vast array of transporters in vitro, current evidence indicates that rOat3 may play an important role in MTX renal elimination, acting in parallel with rRFC-1 at the basolateral membrane of renal proximal tubule cells (13). We therefore sought to determine the in vivo relevance of mOat3 in MTX elimination and distribution utilizing an Oat3 knockout mouse model $(29,30)$. Collectively, findings from pharmacokinetic studies indicate that MTX elimination is impaired in Oat3 knockout mice. When MTX clearance is normalized to that of inulin in order to control for extraneous differences between animals (e.g., hemodynamic variability; 20), it is apparent that Oat3 knockout mice exhibit a significant, albeit modest, reduction in MTX elimination as compared to wildtype mice (Fig. 6a). This observation suggests that Oat3 plays a role in MTX elimination in the intact organism.

MTX clearance was significantly accelerated in male wildtype mice when coadministered with reduced-folates, but this effect was not observed in male knockout mice or female mice of either genotype. This observation suggests that female mice are missing a mechanism which allows reduced folates to stimulate MTX elimination in males. Additionally, it indicates that the stimulatory effect of reduced folates requires functional Oat 3 transporter protein (i.e., reduced folates had no effect on elimination in male knockout mice). Accelerated MTX elimination has been observed before in male rats as a consequence of leucovorin administration (20), but has not been studied before in females. Although it has been suggested that leucovorin may exchange for intracellu-lar MTX to stimulate apical efflux (20), the present findings indicate that the phenomenon is dependent on Oat3 (a basolateral exchanger). Thus, it is possible that intracellular reduced folates, such as leucovorin, can exchange for extracellular MTX on basolateral Oat3, stimulating proximal tubular uptake of MTX. In the present study, it was demonstrated that reduced folates interfere with MTX transport on Oat3 (Fig. 3). On the other hand, female wildtype mice did not demonstrate accelerated MTX elimination in the presence of reduced folates. Therefore, if Oat 3 is being trans-stimulated by apically acquired reduced folates, perhaps female mice do not accumulate reduced folates from the apical aspect as efficiently as males.

Finally, female wildtype mice exhibit significantly greater MTX clearance than male wildtype mice, but the difference is abolished by Oat 3 deletion (Fig. 6b). This indicates that female mice may have greater Oat3 function than males. In a previous study, gender differences in Oat3 mRNA expression were reported in mice, but no clear differences were observed in the C57BL/ 6 strain (31). Investigations in our laboratory indicate that female wildtype C57BL/6 mice express Oat3 mRNA at a level twice as high as males (data not shown), potentially leading to greater Oat3 protein expression. Unfortunately, current tools are not robust enough to investigate mouse Oat3 protein levels.

In order to determine the impact of deletion of Oat 3 on the distribution of MTX, its accumulation was measured in various organs. At $30 \mathrm{~min}$ after its administration, MTX concentrated in the liver and kidneys of mice, but not in the testes, ovaries, skeletal muscle, or brain, reflecting active uptake into liver and kidney (Fig. 7). The liver-to-plasma MTX ratio was four to five times higher than the kidney-to-plasma MTX ratio in wildtype mice at $30 \mathrm{~min}$, despite the fact that MTX is eliminated primarily renally, suggesting that the residence time of MTX in the liver is greater than in the kidneys. Absolute renal and hepatic MTX levels were also plotted in order to determine inherent differences in the organs (Fig. 8). The observation that kidney levels of MTX were markedly reduced in wildtype, but not Oat 3 knockout, males in response to reduced folates (Fig. 8a) agrees with the heightened clearance observed under these conditions (Fig. 6a), and indicates that renal residence time of MTX may be shortened in wildtype males, but not Oat3 knockouts, when administered reduced folates. This observation in wildtype male mice agrees with a previous report in male rats (20). However, the observation that females are virtually unresponsive to reduced folate administration, with 
respect to MTX disposition, has not been previously reported. Additionally, the discovery that Oat3 knockout males do not respond to reduced folates, with respect to renal accumulation, as do wildtype males, suggests that the stimulatory effect on reduced folate clearance is dependent on Oat 3 function. Therefore, Oat 3 possibly facilitates stimulation of renal secretion by reduced folates. The finding that male mice are sensitive to inhibition by reduced folates, with respect to liver accumulation, but female mice exhibit a minimal response, indicates that an inherent difference exists within the liver itself, between genders. Since absolute liver accumulation was similar between males and females in the absence of reduced folates, but exhibited a large gender difference in response to reduced folates, it appears that males and females have evolved hepatic transport functions of equal efficiency, but differential mechanisms, at least for MTX.

\title{
CONCLUSION
}

In conclusion, the present findings suggest that mouse Oat 3 interacts with MTX much like the human ortholog with respect to transport kinetics and drug interactions. Furthermore, folate and reduced folates can cis-inhibit MTX transport on mOat3. Deletion of Oat3 resulted in significantly impaired MTX clearance in mice. Therefore, compromised human OAT3, whether resulting from protein-altering single-nucleotide polymorphisms or from drug substrate overload (e.g., polypharmacy involving NSAIDs, penicillins, or urico-surics such as probenecid), may not substantially impact MTX elimination unless redundant means of removal are also impaired. Future investigations are necessary to dissect out the individual roles of each carrier in multifactorial MTX secretory transport. In addition to elucidating the role of Oat3 in MTX disposition, this investigation also highlighted major gender differences in mice with respect to MTX reduced folate drug-drug interactions. Males appear to have both an Oat3-dependent renal MTX secretory mechanism and an Oat3-independent hepatic MTX transport mechanism that are sensitive to reduced folates, which females are lacking.

Regardless of Oat3's role in total plasma clearance of MTX, this renal basolateral exchanger likely plays a substantial role in mediating methotrexate proximal tubular neph-rotoxicity, as a previous investigation found that rOat 3 is responsible for approximately $50 \%$ of renal basolateral MTX uptake (13). Thus, it is possible that concomitant hOAT3 substrate administration can reduce the nephrotoxic effects of MTX. Of course, this action may raise the systemic level of MTX if a compound with renal transporter multispecificity is used, e.g., an NSAID inhibiting OATs and MRPs, a consequence that has been observed previously in humans (1). Therefore, with careful monitoring, it may be feasible for clinicians to reduce the MTX dose used in their patients by coadministration of an Oat3 substrate, resulting in a reduced potential for nephrotoxicity, but therapeutic plasma levels.

\section{Acknowledgments}

This work was supported by National Institute of Diabetes and Digestive and Kidney Diseases Grant R01-DK-067216 (D.H.S.), by fellowship provisions from the American Foundation for Pharmaceutical Education (A.L.V.), and by the National Institutes of Health Grant Number C06 RR015455 from the Extramural Research Facilities Program of the National Center for Research Resources.

\section{ABBREVIATIONS}

\author{
5- $\mathrm{CH}_{3}$ - $\mathrm{THF}$-methyltetrahydrofolate \\ 5-CHO-THF $\quad$ 5-formyltetrahydrofolate (a.k.a. folinic acid or leucovorin) \\ 5-HIAA 5-hydroxyindoleacetic acid \\ CHO-FRT Chinese hamster ovary cells transfected with empty vector
}


CHO-mOat3 Chinese hamster ovary cells transfected with murine organic anion transporter 3

DOPAC dihydroxyphenylacetic acid

$\mathrm{h}$

$K_{\mathrm{m}}$

m

MRP

MTX

NSAIDs

OAT or Oat

r

RFC-1 human

the Michaelis-Menten constant

mouse

multidrug resistance-associated protein

methotrexate

non-steroidal anti-inflammatory drugs

human or non-human organic anion transporter, respectively

rat

reduced folate carrier 1

\section{REFERENCES}

1. Methotrexate. DRUGDEX ${ }^{\circledR}$ Evaluations. n.d. Thomson Micro-medex. Mar. 14. 2007 Available at: http://www.thomsonhc.com

2. Widemann BC, Adamson PC. Understanding and managing methotrexate nephrotoxicity. Oncologist 2006;11:694-703. [PubMed: 16794248]

3. White JC, Goldman ID. Mechanism of action of methotrexate. IV. Free intracellular methotrexate required to suppress dihydrofolate reduction to tetrahydrofolate by Ehrlich ascites tumor cells in vitro. Mol. Pharmacol 1976;12:711-719. [PubMed: 1033456]

4. White JC, Loftfield S, Goldman ID. The mechanism of action of methotrexate. III. Requirement of free intracellular methotrexate for maximal suppression of (14C)formate incorporation into nucleic acids and protein. Mol. Pharmacol 1975;11:287-297. [PubMed: 1170491]

5. Wright SH, Dantzler WH. Molecular and cellular physiology of renal organic cation and anion transport. Physiol. Rev 2004;84:987-1049. [PubMed: 15269342]

6. Sweet DH, Bush KT, Nigam SK. The organic anion transporter family: from physiology to ontogeny and the clinic. Am. J. Physiol. Renal. Physiol 2001;281:F197-205. [PubMed: 11457711]

7. Sweet DH. Organic anion transporter (Slc22a) family members as mediators of toxicity. Toxicol. Appl. Pharmacol 2005;204:198-215. [PubMed: 15845414]

8. El-Sheikh AA, van den Heuvel JJ, Koenderink JB, Russel FG. Interaction of nonsteroidal antiinflammatory drugs with multidrug resistance protein (MRP) 2/ABCC2- and MRP4/ABCC4-mediated methotrexate transport. J. Pharmacol. Exp. Ther 2007;320:229-235. [PubMed: 17005917]

9. Kool M, van der Linden M, de Haas M, Scheffer GL, de Vree JM, Smith AJ, Jansen G, Peters GJ, Ponne N, Scheper RJ, Elferink RP, Baas F, Borst P. MRP3, an organic anion transporter able to transport anti-cancer drugs. Proc. Natl. Acad. Sci. U. S. A 1999;96:6914-6919. [PubMed: 10359813]

10. Rau T, Erney B, Gores R, Eschenhagen T, Beck J, Langer T. High-dose methotrexate in pediatric acute lympho-blastic leukemia: impact of $\mathrm{ABCC} 2$ polymorphisms on plasma concentrations. Clin. Pharmacol. Ther 2006;80:468-476. [PubMed: 17112803]

11. Letourneau IJ, Bowers RJ, Deeley RG, Cole SP. Limited modulation of the transport activity of the human multidrug resistance proteins MRP1, MRP2 and MRP3 by nicotine glucuronide metabolites. Toxicol. Lett 2005;157:9-19. [PubMed: 15795089]

12. Brigle KE, Spinella MJ, Sierra EE, Goldman ID. Characterization of a mutation in the reduced folate carrier in a transport defective L1210 murine leukemia cell line. J. Biol. Chem 1995;270:22974 22979. [PubMed: 7559435]

13. Nozaki Y, Kusuhara H, Endou H, Sugiyama Y. Quantitative evaluation of the drug-drug interactions between methotrexate and nonsteroidal anti-inflammatory drugs in the renal uptake process based 
on the contribution of organic anion transporters and reduced folate carrier. J. Pharmacol. Exp. Ther 2004;309:226-234. [PubMed: 14722319]

14. Badagnani I, Castro RA, Taylor TR, Brett CM, Huang CC, Stryke D, Kawamoto M, Johns SJ, Ferrin TE, Carlson EJ, Burchard EG, Giacomini KM. Interaction of methotrexate with organic-anion transporting polypeptide 1A2 and its genetic variants. J. Pharmacol. Exp. Ther 2006;318:521-529. [PubMed: 16702441]

15. Saito H, Masuda S, Inui K. Cloning and functional characterization of a novel rat organic anion transporter mediating basolateral uptake of methotrexate in the kidney. J. Biol. Chem 1996;271:20719-20725. [PubMed: 8702823]

16. Takeuchi A, Masuda S, Saito H, Abe T, Inui K. Multispecific substrate recognition of kidney-specific organic anion transporters OAT-K1 and OAT-K2. J. Pharmacol. Exp. Ther 2001;299:261-267. [PubMed: 11561088]

17. Sweet DH, Wolff NA, Pritchard JB. Expression cloning and characterization of rOat1. The basolateral organic anion transporter in rat kidney. J. Biol. Chem 1997;272:30088-30095. [PubMed: 9374486]

18. Sweet DH, Chan LM, Walden R, Yang XP, Miller DS, Pritchard JB. Organic anion transporter 3 (Slc22a8) is a dicarboxylate exchanger indirectly coupled to the Na+ gradient. Am. J. Physiol. Renal. Physiol 2003;284:F763-769. [PubMed: 12488248]

19. Witt TL, Stapels SE, Matherly LH. Restoration of transport activity by co-expression of human reduced folate carrier half-molecules in transport-impaired K562 cells: localization of a substrate binding domain to transmembrane domains 7-12. J. Biol. Chem 2004;279:46755-46763. [PubMed: 15337749]

20. He YL, Tanigawara Y, Yasuhara M, Hori R. Effect of folinic acid on tissue residence and excretion of methotrexate in rats. Drug Metab. Dispos 1991;19:729-734. [PubMed: 1680647]

21. Erdman AR, Mangravite LM, Urban TJ, Lagpacan LL, Castro RA, de la Cruz M, Chan W, Huang CC, Johns SJ, Kawamoto M, Stryke D, Taylor TR, Carlson EJ, Ferrin TE, Brett CM, Burchard EG, Giacomini KM. The human organic anion transporter 3 (OAT3; SLC22A8): genetic variation and functional genomics. Am. J. Physiol. Renal. Physiol 2006;290:F905-912. [PubMed: 16291576]

22. Brady KP, Dushkin H, Fornzler D, Koike T, Magner F, Her H, Gullans S, Segre GV, Green RM, Beier DR. A novel putative transporter maps to the osteosclerosis (oc) mutation and is not expressed in the oc mutant mouse. Genomics 1999;56:254-261. [PubMed: 10087192]

23. Schnabolk GW, Youngblood GL, Sweet DH. Transport of estrone sulfate by the novel organic anion transporter Oat6 (Slc22a20). Am. J. Physiol. Renal. Physiol 2006;291:F314-321. [PubMed: 16478971]

24. Uwai Y, Taniguchi R, Motohashi H, Saito H, Okuda M, Inui K. Methotrexate-loxoprofen interaction: involvement of human organic anion transporters hOAT1 and hOAT3. Drug Metab. Pharmacokinet 2004;19:369-374. [PubMed: 15548848]

25. Takeda M, Khamdang S, Narikawa S, Kimura H, Hosoyamada M, Cha SH, Sekine T, Endou H. Characterization of methotrexate transport and its drug interactions with human organic anion transporters. J. Pharmacol. Exp. Ther 2002;302:666-671. [PubMed: 12130730]

26. Kneuer C, Honscha KU, Honscha W. Rat reduced-folate carrier-1 is localized basolaterally in MDCK kidney epithelial cells and contributes to the secretory transport of methotrexate and fluoresceinated methotrexate. Cell Tissue Res 2005;320:517-524. [PubMed: 15846510]

27. Burckhardt BC, Burckhardt G. Transport of organic anions across the basolateral membrane of proximal tubule cells. Rev. Physiol. Biochem. Pharmacol 2003;146:95-158. [PubMed: 12605306]

28. Takeuchi A, Masuda S, Saito H, Doi T, Inui K. Role of kidney-specific organic anion transporters in the urinary excretion of methotrexate. Kidney Int 2001;60:1058-1068. [PubMed: 11532100]

29. Sykes D, Sweet DH, Lowes S, Nigam SK, Pritchard JB, Miller DS. Organic anion transport in choroid plexus from wild-type and organic anion transporter 3 (Slc22a8)-null mice. Am. J. Physiol. Renal. Physiol 2004;286:F972-978. [PubMed: 15075193]

30. Sweet DH, Miller DS, Pritchard JB, Fujiwara Y, Beier DR, Nigam SK. Impaired organic anion transport in kidney and choroid plexus of organic anion transporter 3 (Oat3 (Slc22a8)) knockout mice. J. Biol. Chem 2002;277:26934-26943. [PubMed: 12011098] 
31. Buist SC, Klaassen CD. Rat and mouse differences in gender-predominant expression of organic anion transporter (Oat1-3; Slc22a6-8) mRNA levels. Drug Metab. Dispos 2004;32:620-625. [PubMed: 15155553]

32. Cha SH, Sekine T, Fukushima JI, Kanai Y, Kobayashi Y, Goya T, Endou H. Identification and characterization of human organic anion transporter 3 expressing predominantly in the kidney. Mol. Pharmacol 2001;59:1277-1286. [PubMed: 11306713] 

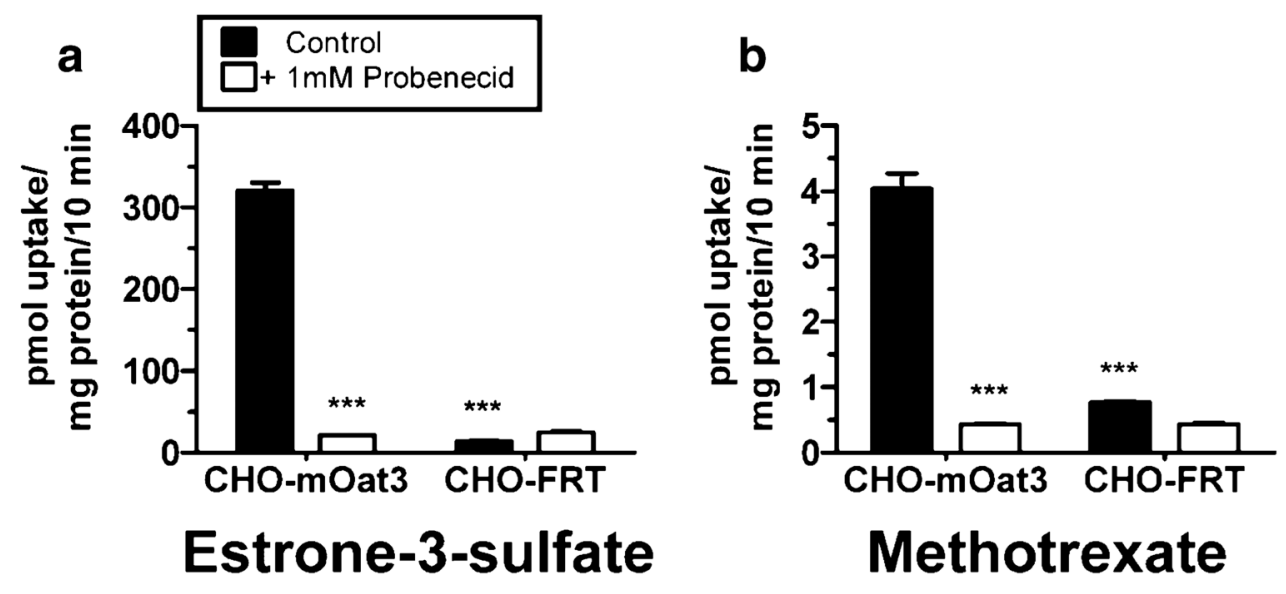

Fig. 1.

Transport of estrone-3-sulfate and MTX by murine Oat3. Uptake was measured for $10 \mathrm{~min}$ at room temperature in Chinese hamster ovary cells stably transfected with mOat3 (CHO-mOat3) or empty vector (CHO-FRT). a Uptake of $\left[{ }^{3} \mathrm{H}\right]$ estrone-3-sulfate $(5 \mu \mathrm{M})$ in the presence or absence of probenecid $(1 \mathrm{mM})$. b Uptake of $\left[{ }^{3} \mathrm{H}\right] \mathrm{MTX}(1 \mu \mathrm{M})$ in the presence or absence of probenecid $(1 \mathrm{mM})$. Asterisks represent significant differences from respective mOat 3 control uptake $(* * *, p<0.001)$. Values are mean \pm SE. 
a

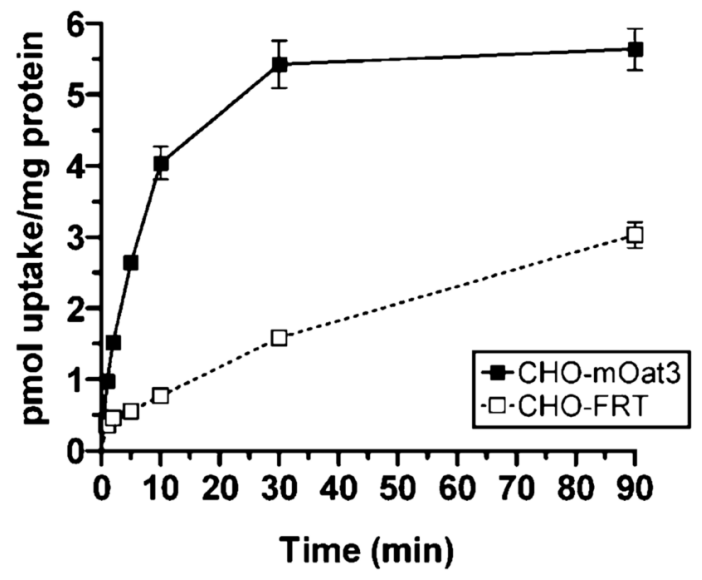

b

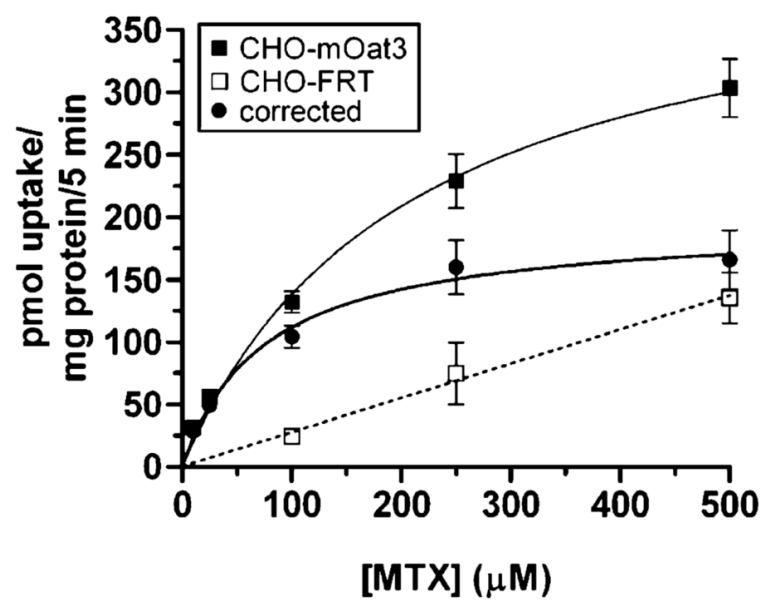

C

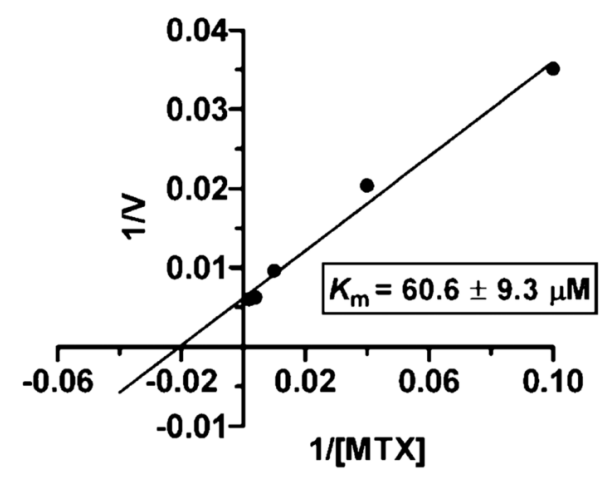

Fig. 2.

Timecourse and Michaelis-Menten Kinetics of MTX transport in CHO-mOat3 cells. a Uptake of $\left[{ }^{3} \mathrm{H}\right] \mathrm{MTX}(1 \mu \mathrm{M})$ was measured for $1,2,5,10,30$, and $90 \mathrm{~min}$ at room temperature in CHOmOat 3 and CHO-FRT cells in order to determine the linear accumulation phase. $\mathbf{b}$ Uptake of $\left[{ }^{3} \mathrm{H}\right] \mathrm{MTX}(10,25,100,250$, and $500 \mu \mathrm{M})$ was measured for $5 \mathrm{~min}$ at room temperature in CHO-mOat 3 and CHO-FRT cells in order to construct a saturation curve. The "corrected" curve was obtained by subtracting the background nonspecific uptake as measured in the CHOFRT cells from mOat3-mediated uptake. c Lineweaver-Burk plot of the "corrected" uptake values. The estimated $K^{\mathrm{m}}$ calculated from three independent experiments conducted in triplicate is $60.6 \pm 9.3 \mu \mathrm{M}$. Values are mean $\pm \mathrm{SE}$. 


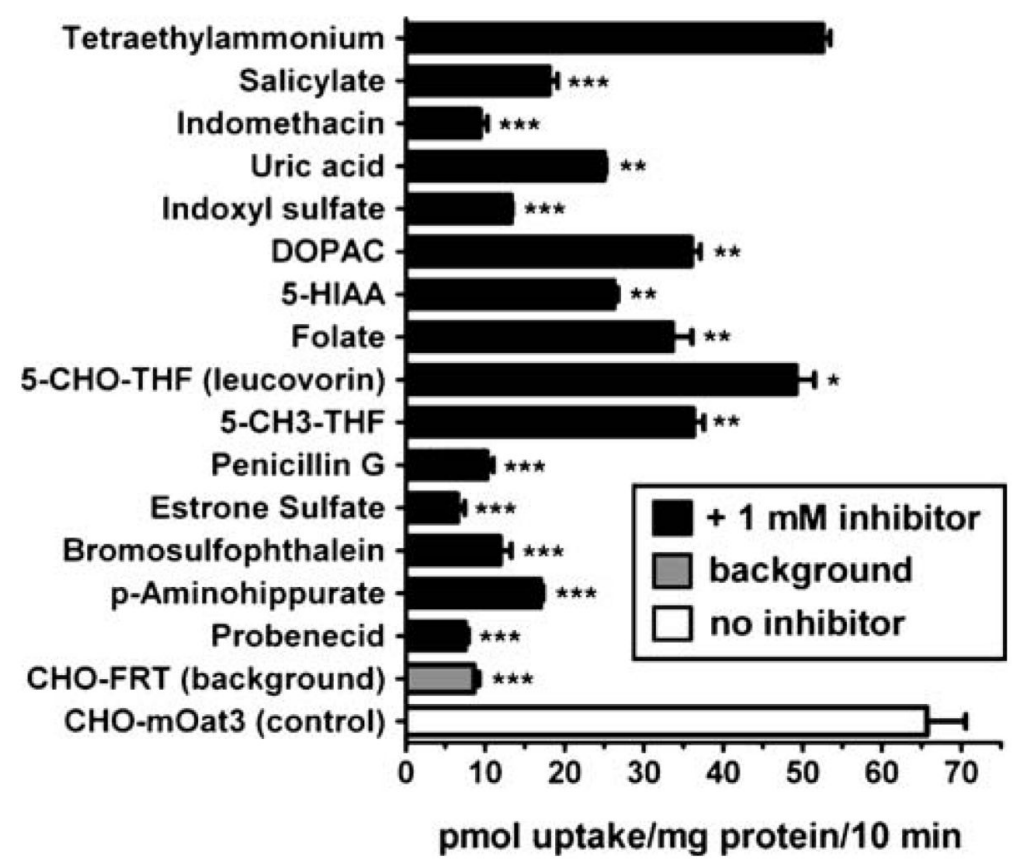

Fig. 3.

Inhibition profile of organic anions competing with MTX transport in CHO-mOat3 cells. Uptake of $\left[{ }^{3} \mathrm{H}\right] \mathrm{MTX}(10 \mu \mathrm{M})$ in CHO-mOat 3 cells was measured for $10 \mathrm{~min}$ at room temperature in the presence $(1 \mathrm{mM})$ or absence of organic anions, and the organic cation tetraethylammonium. Background in CHO-FRT cells was determined in the absence of inhibitor. Asterisks represent significant differences from $\mathrm{CHO}-\mathrm{mOat} 3$ control $(*, p<0.05$; **, $p<0.01$; ***, $p<0.001)$. Abbreviations: DOPAC (dihydroxyphenylacetic acid), 5-HIAA (5hydroxyindoleacetic acid), 5-CHO-THF (5-formyltetrahydrofolate), and 5- $\mathrm{CH}^{3}-\mathrm{THF}$ (5methyltetrahydrofolate). Values are mean \pm SE. 
a

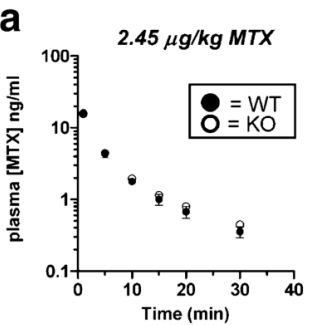

d

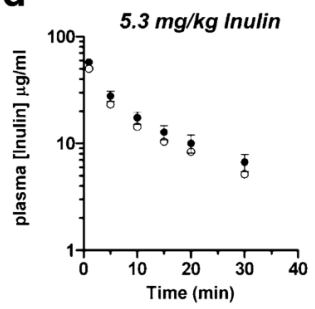

b

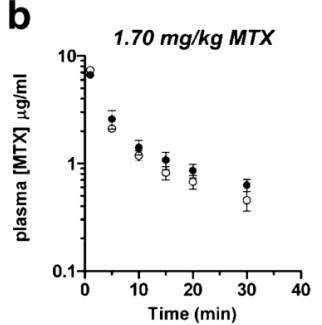

e

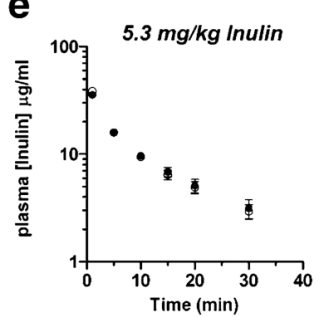

C

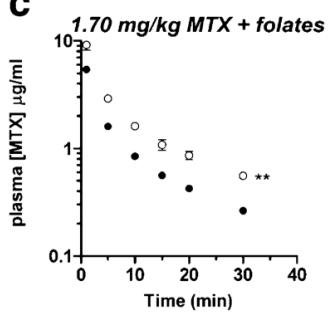

f

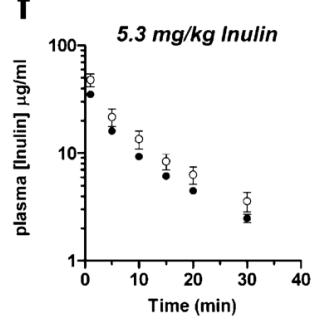

Fig. 4.

Plasma elimination of MTX in male wildtype and Oat 3 knockout mice in the presence or absence of reduced folates. a Plasma elimination of $\left[{ }^{3} \mathrm{H}\right] \mathrm{MTX}$ after a $2.45 \mu \mathrm{g} / \mathrm{kg}$ dose. b Plasma elimination of $\left[{ }^{3} \mathrm{H}\right] \mathrm{MTX}$ after a $1.7 \mathrm{mg} / \mathrm{kg}$ dose. c Plasma elimination of $\left[{ }^{3} \mathrm{H}\right] \mathrm{MTX}(1.7 \mathrm{mg} /$ $\mathrm{kg}$ ) in the presence of a tenfold molar excess of 5-methyltetrahydrofolate and 5formyltetrahydrofolate (leucovorin). d-f Plasma elimination of $\left[{ }^{14} \mathrm{C}\right]$ inulin injected concomitantly with $\left[{ }^{3} \mathrm{H}\right] \mathrm{MTX}$ (charts correspond vertically). Asterisks represent significant differences between the entire elimination curves using two-way ANOVA ( $* *, p<0.01)$. Significant differences were present between the curves in $\mathbf{c}$ only. $N=3$ animals for each curve and values given are mean \pm SE. Note: units on $\mathrm{y}$-axis of a are $\mathrm{ng} / \mathrm{ml}$. 

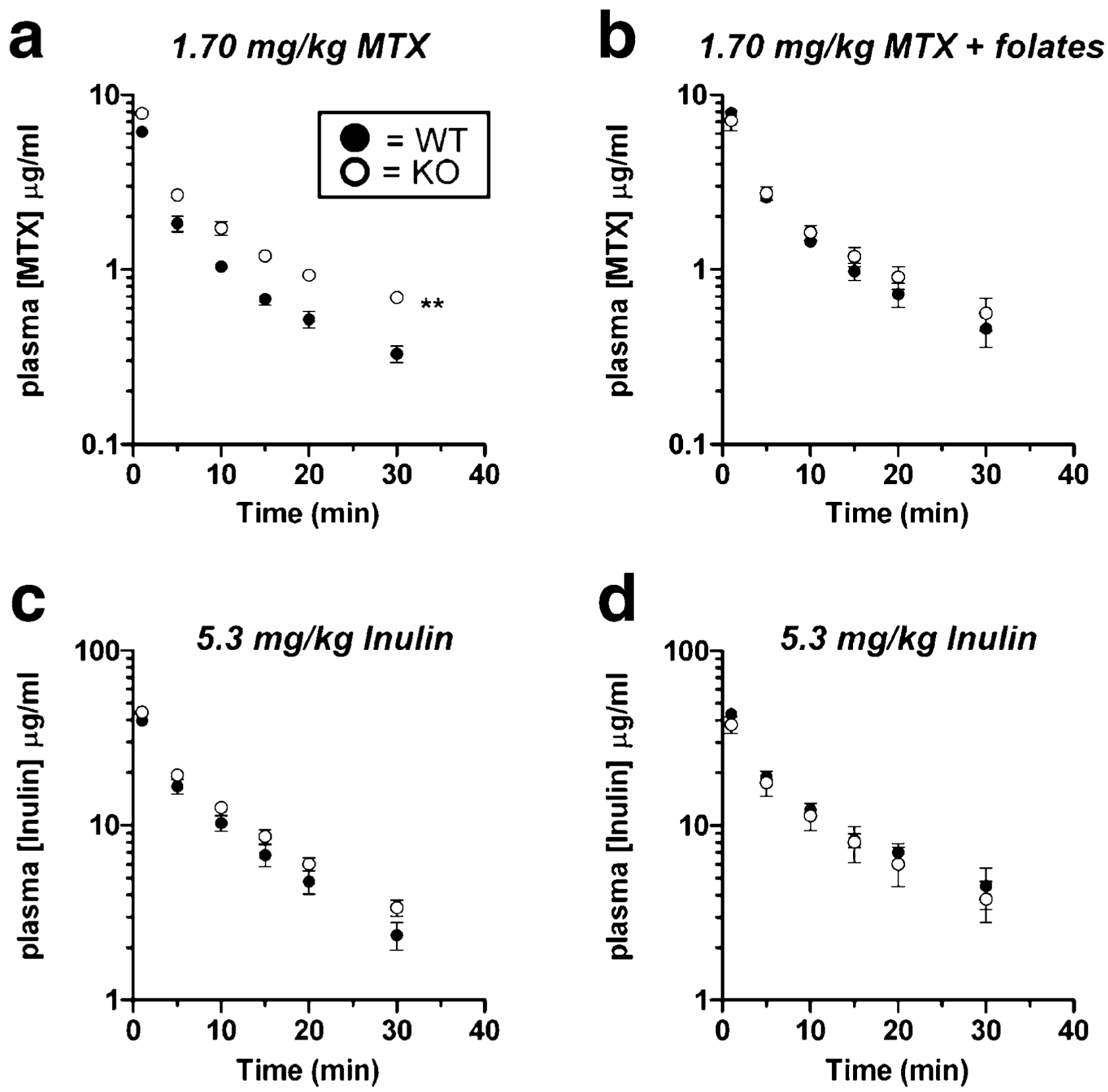

Fig. 5.

Plasma elimination of MTX in female wildtype and Oat3 knockout mice in the presence or absence of reduced folates. a Plasma elimination of $\left[{ }^{3} \mathrm{H}\right] \mathrm{MTX}$ after a $1.7 \mathrm{mg} / \mathrm{kg}$ dose. b Plasma elimination of $\left[{ }^{3} \mathrm{H}\right] \mathrm{MTX}(1.7 \mathrm{mg} / \mathrm{kg})$ in the presence of a tenfold molar excess of 5methyltetrahydrofolate and 5-formyltetrahydrofolate (leucovorin). $\mathbf{c}$ and $\mathbf{d}$ Plasma elimination of $\left[{ }^{14} \mathrm{C}\right]$ inulin injected concomitantly with $\left[{ }^{3} \mathrm{H}\right] \mathrm{MTX}$ (charts correspond vertically).

Asterisks represent significant differences between the entire elimination curves using twoway ANOVA $(* *, p<0.01)$. Significant differences were present between the curves in a only. $N=3$ animals for each curve and values given are mean \pm SE. 
a

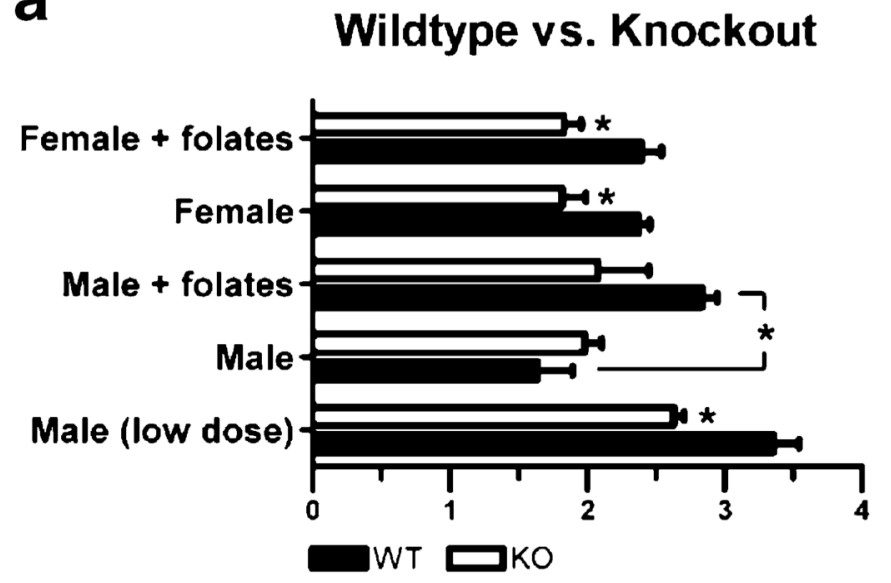

b

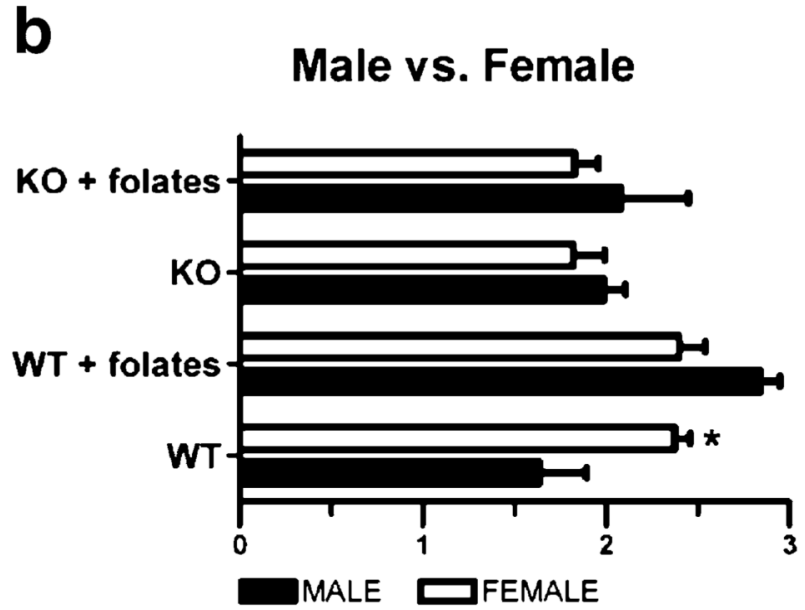

\section{Methotrexate:Inulin Clearance Ratio}

Fig. 6.

MTX-to-inulin plasma clearance ratio comparing genotypes and genders. Ratios were determined using MTX and inulin plasma clearance values for each individual mouse. The mean inulin plasma clearance value for all mice in this investigation is considered typical (13.57 $\pm 0.64 \mathrm{ml} \mathrm{min}^{-1} \mathrm{~kg}^{-1}, n=30$ ). a Comparison between wildtype (WT) and Oat3 knockout $(K O)$ mice in the presence (denoted as+folates) or absence of reduced folates. $b$ Comparison between male and female mice in the presence or absence of reduced folates. Asterisks represent significant differences between genotypes (a) and genders (b) or any other indicated bars (*, $p<0.05)$. Clearance values were generated from the data used in Figs. 4 and 5. $N=3$ animals for each bar and values given are mean \pm SE. All ratios are calculated from data obtained in the "clinical dose" (i.e., $1.7 \mathrm{mg} / \mathrm{kg}$ ) methotrexate experiments with the exception of "low dose" for males, which was obtained using data from the tracer dose experiment. 

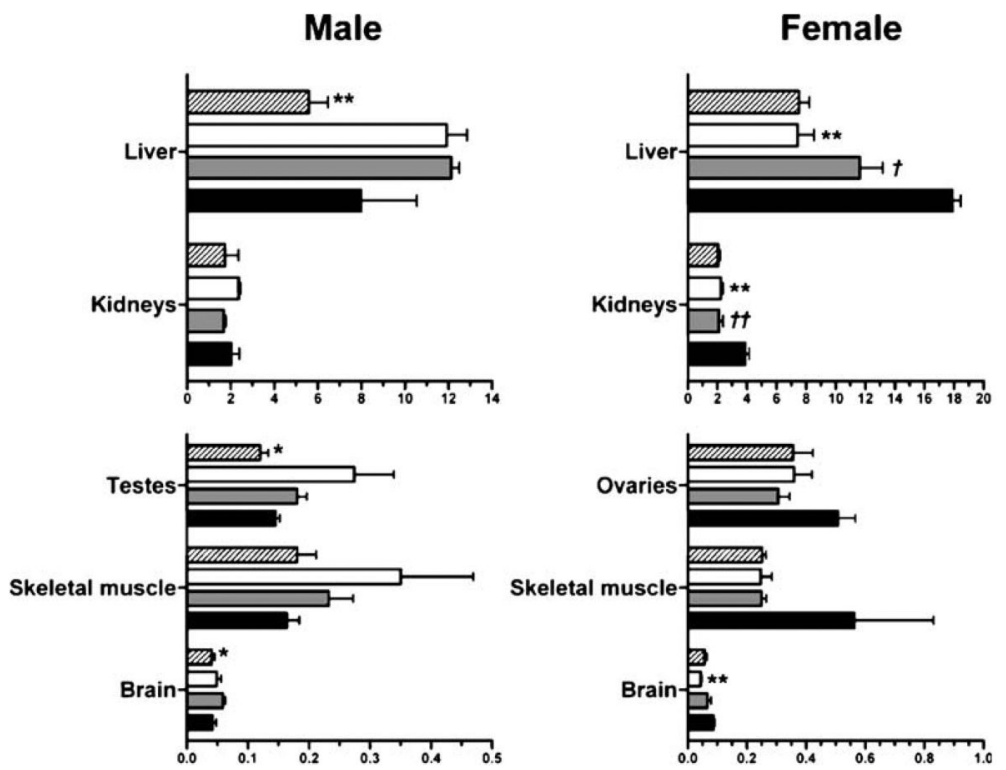

Tissue:Plasma Methotrexate Ratio

WT

$\square \mathrm{WT}+$ folates

\section{$\square \mathrm{KO} \mathrm{KO}+$ folates}

Fig. 7.

Tissue-to-plasma ratio of MTX in wildtype and Oat3 knockout mice in the presence or absence of reduced folates. Thirty minutes after IV bolus [ $\left.{ }^{3} \mathrm{H}\right]$ MTX (Figs. 4 and 5) in the presence or absence of reduced-folate inhibition, the indicated tissues were harvested and $\left[{ }^{3} \mathrm{H}\right] \mathrm{MTX}$ levels were quantified. Thirty-minute plasma MTX levels were used to calculate the tissue-to-plasma ratios. Asterisks represent significant differences between wildtype and Oat 3 knockout mice given the same treatment (i.e., with or without reduced-folate inhibition), and for the same tissue and gender $(*, p<0.05 ; * *, p<0.01)$. Daggers represent significant differences between mice of the same genotype in the presence or absence of folates $(\dagger, p<0.05$;,$p<0.01)$. Values are mean $\pm \mathrm{SE}$. 

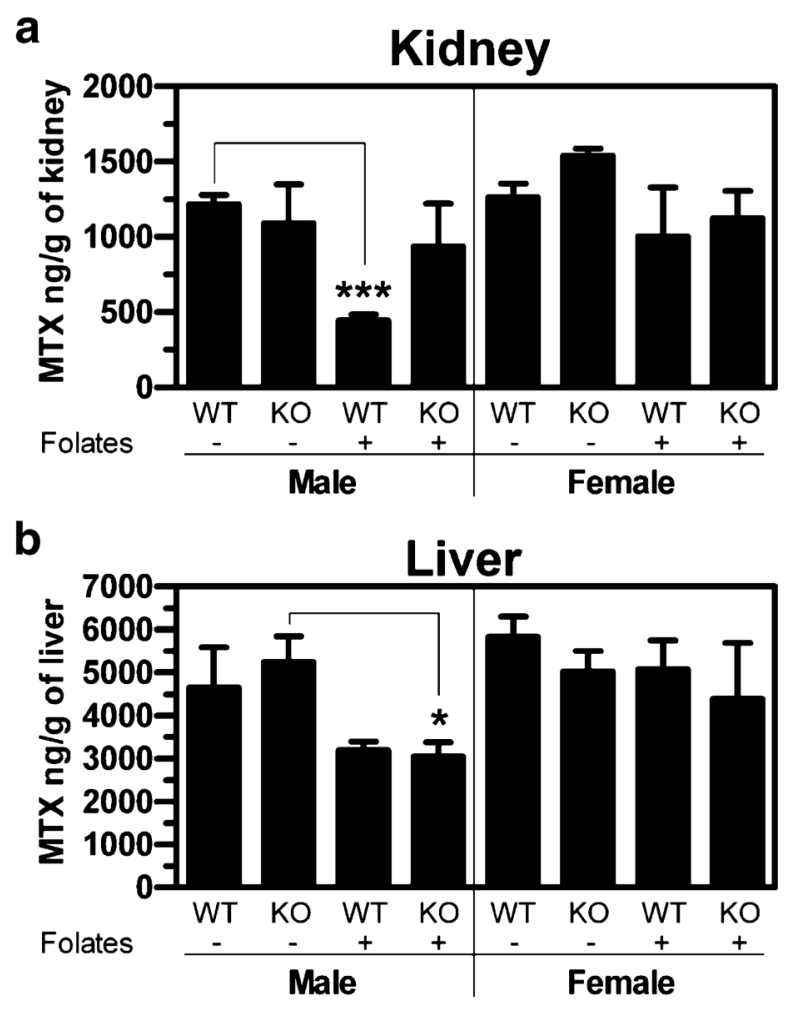

Fig. 8.

Absolute kidney and liver accumulation of MTX in wildtype and Oat3 knockout mice. Thirty minutes after IV bolus $\left[{ }^{3} \mathrm{H}\right] \mathrm{MTX}$ (Figs. 4 and 5) in the presence or absence of reduced folates, kidneys (a) and liver (b) were harvested and $\left[{ }^{3} \mathrm{H}\right] \mathrm{MTX}$ levels were quantified. WT, wildtype mice; $K O$, Oat3 knockout mice; -, absence of folates; +, presence of folates. Asterisks represent significant differences between the indicated $\operatorname{bars}(*, p<0.05) . N=3$ animals and values given are mean \pm SE. 


\section{Table I}

MTX Transport Kinetics in Heterologous Expression Systems

\begin{tabular}{|c|c|c|c|}
\hline Transporter & Expression System & $K_{\mathrm{m}} \pm \mathrm{SE}(\mu \mathrm{M})$ & Reference \\
\hline \multirow[t]{2}{*}{ hOAT1 } & Xenopus oocyte & $724 \pm 74.9$ & (24) \\
\hline & $\mathrm{S}_{2} \mathrm{MRPTC}^{a}$ & $553.8 \pm 43.2$ & (25) \\
\hline rOat1 & LLC-PK 1 cells & $14.9 \pm 0.8$ & (13) \\
\hline \multirow[t]{3}{*}{ hOAT3 } & Xenopus oocyte & $17.2 \pm 3.6$ & (24) \\
\hline & & $10.9 \pm 1.7$ & $(32)$ \\
\hline & $\mathrm{S}_{2} \mathrm{MRPTC}^{a}$ & $21.1 \pm 2.8$ & $(25)$ \\
\hline mOat3 & CHO cells & $60.6 \pm 9.3$ & Current study \\
\hline hOAT4 & $\mathrm{S}_{2} \mathrm{MRPTC}^{a}$ & $17.8 \pm 1.6$ & (25) \\
\hline hMRP2 & HEK293 cell membrane vesicles & $480 \pm 90$ & (8) \\
\hline hMRP4 & HEK293 cell membrane vesicles & $220 \pm 70$ & (8) \\
\hline rRfc-1 & MDCKII cells & $17.8 \pm 1.8$ & (13) \\
\hline hOATP1A2 & Xenopus oocyte & $457 \pm 118$ & (14) \\
\hline \multirow[t]{2}{*}{ rOat-K1 } & MDCK cells & $2.1^{b}$ & (16) \\
\hline & LLC-PK $_{1}$ cells & $1.0^{b}$ & (15) \\
\hline rOat-K2 & MDCK cells & $1.8^{b}$ & (16) \\
\hline
\end{tabular}

Species abbreviations: $h$ Human, $r$ rat, $m$ mouse

${ }^{a}$ Immortalized mouse renal $\mathrm{S}_{2}$ proximal tubule cell line stably transfected with the indicated transporter.

${ }^{b}$ Standard errors were not reported. 